\title{
Psycholinguistic Mechanisms for Actualization of Translating Activities of the Interpreter
}

\section{Психолінгвістичні механізми актуалізації перекладацької діяльності перекладача}

\author{
Ernest Ivashkevych ${ }^{1}$ \\ Ph.D. in Psychology, \\ Senior Lecturer, \\ Translator
}

\author{
Ернест Івашкевич ${ }^{1}$ \\ кандидат психологічних наук, \\ старший викладач, \\ перекладач
}

\author{
E-mail: erikguetta@mail.ru \\ https://orcid.org/0000-0001-7219-1086 \\ ResearcherID: F-3865-2019
}

Alla Yatsjuryk ${ }^{2}$

Ph.D. in Psychology,

Assistant Professor
Алла Яцюрик ${ }^{2}$

кандидат психологічних наук, доцент

$$
\begin{gathered}
\text { E-mail: yatsiuryk.a@gmail.com } \\
\text { https://orcid.org/0000-0003-3933-8503 } \\
\text { ResearcherID: F-3174-2019 }
\end{gathered}
$$

${ }^{1}$ Rivne State University

of the Humanities

12, Stepan Bandera Str., Rivne, Ukraine, 33000

${ }^{2}$ International Economic and

Humanitarian University

named after Academician

Stepan Demyanchuk

4, Stepan Demyanchuk Str.,

Rivne, Ukraine, 33000
'Рівненський державний гуманітарний університет $\checkmark$ вул. Степана Бандери, 12, Рівне, Україна, 33000

${ }^{2}$ Міжнародний економікогуманітарного університет імені академіка

Степана Дем'янчука

$\triangle$ вул. Степана Дем'янчука, 4, Рівне, Україна, 33000

Original manuscript received August 20, 2019

Revised manuscript accepted February 28, 2020 


\section{ABSTRACT}

The purpose of the article is to propose and justify the definition of "translation consciousness" of the interpreter.

Methods of the research. The methods of the research are: theoretical ones categorical analysis, the methods of systematization, modeling, generalization; empirical methods - the analysis of documents, the analysis of products of the activity, the content analysis of the novel.

The results of the research. It was distinguished that the translation consciousness should be considered not only as a construct, a system of signs, but also as a phenomenon that exploded the system of knowledge about the world, as well as the particularities of using the strategies for the implementation of translation activities. Consequently, the translation consciousness is being facilitated, first of all, by the existence of various images of the world in the consciousness of the translator, images, which allows the interpreter to perform cognitive processing at a high level. Also in the conceptual system of the translator, they must be syncretically represented, although within the various theoretical paradigms differently structured by so called "native» and "in-cultural» concepts. We emphasize the special role of the translation consciousness, its media function in the translation activity, which ensures the ability of a translator to form a multidimensional system of relationships in their own consciousness. The latter facilitates the success of translation activities.

Conclusions. The translation consciousness is the ability of the interpreter to carry out his/her professional activities, to reflect, adequately reflect the translation situation, as well as to establish his/her attitude towards the performance of the activity. The necessary component of the translation consciousness is knowledge, as well as the experience of the interpreter that it is the most significant in translating. In such a way the translation consciousness ensures the performance of translation activities at three levels: at associative one, at topical level and also at integrative one.

Key words: the mechanism of orientation, selection and presentation of the translation solution; the mechanism of additional expressiveness; the mechanism of freedom in interpretation.

\section{Introduction}

The professional activity of a translator is a very complicated process from the psychological point of view. Its understanding involves the implementation of the integrative approach that synthesizes the theoretical positions of psycholinguistics, semiotics, cognitive linguistics and intercultural communication. As a rule, when telling about translation activity scientists offer the concept of verbal mediating activity of a specialist, with the aim to implement intercultural 
communication, in which the qualities of speech of the person are the determinants of translation.

The concepts «speech mediation», «speech mediator» in the most general form are revealed by the analysis of the process of communication in two languages (original one and the language of translation) by the third person - the mediator (Gutt, 1998). In the process of implementing certain types of speech mediation (we mean translation, abstracting, compressed translation, «designing» the text), the mediator assumes the responsibility to make certain changes according to formal and content sides of the text (Kolomiets, 2011). In this case, the secondary text activity may be accompanied by compression, deployment, restructuring, commenting, parodying and, even, creation of a completely new text, and the mediator becomes to play a role of a full co-author of a new text (Karaban, 2004). Therefore, it is quite understandable that translation activity is generally recognized as the integral process of speech mediation (Lörscher, 1993). The translator always strives to correlate so-called «language codes», frames and scripts with the peculiarities of the outlook and mentality of partners of communication, to achieve the most adequate perception of the text material, bringing the process of translation activity closer to monolingual communication (Nida \& Taber, 1969).

The indirect nomination of a translator in both languages

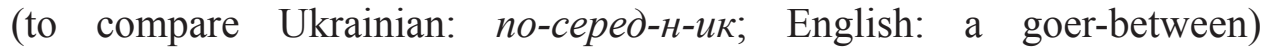
actualizes the person's central status position, emphasizing his/her place in the process of communication, but in this content mediation also performs the function of «reconciliation» (Tolkovyj slovar, n.d.) on the translator. For example, in the dictionary this term is interpreted in such a way:

"Mediation is the process of promoting the agreement or reconciliation between two partners of communication», "the mediator is a peacemaker between two opposite "parties» (Tolkovyj slovar, n.d.).

The mediating function of a translator always is on the border of the existence of two consciousness; it is the interaction of two subjects, the intersection of two languages and two cultures; under the condition of updating the mediating function, as a rule, the process of translation activity is provided (Kovganyuk, 1968). 
Telling about psycholinguistic mechanisms of translation, there is always actualization of basic problems of many humanities, which allow all possible connections between a foreign language and the person's consciousness, thinking and speech. Perceptions of these relationships are always debatable, and their understanding is usually determined by the philosophical and epistemological paradigms, which are of particular priority, including the point of view adopted by a scientific community. Anthropocentrism of Contemporary Psychology has contributed to the emergence of a completely new approach to a language as means of actualization of mental processes, which determine the desire of researchers to find verified correlations between the operative units of consciousness and their objectifying linguistic signs (Ness \& MeltzerAsscher, 2017). This requires further development of approaches according to translation activity not only as a method of studying linguistic phenomena, thus more clearly highlighting translation activity's latent characteristics, but also as one of the types of explication of a mental model of the world by a translator (Zorivchak, 1983). So, the system of meanings, presented in the original and translated texts, has the aim to interpret the values of consciousness of the author of the text, and constitutes concepts of displaying by the translator the basic ways of knowing the surrounding reality, which allows to qualify the translation as a speech-thinking process, a dominant role in which mental models play. In this case, all translation operations are necessarily have to be fixed in translated text, it is a kind of «meta-text» of understanding the information.

If we tell about translation activity, we have to understand that it is a specific kind of the activity. The nature of the translation activity is largely due to the relationship of the mediated language of a specialist in the world of speech and speech activity, in which the person takes the central position.

The purpose of the article is to propose and justify the definition of «translation consciousness» of the interpreter.

So, the tasks of our research are:

(1). To distinguish psychological mechanisms for actualization of translating activities of the interpreter.

(2). To analyze these psychological mechanisms using the examples of the translation of the novel «The Catcher in the Rye» (the author of it is J.D. Salinger (1984)) by O. Lohvynenko, and 
the examples of the translation of the novel «SlaughterhouseFive or The Children's Crusade: A Duty-Dance with Death» (the author of it is K. Vonnegut (2006)) by P. Sokolovskyi.

\section{Methods and Methodical Instrumentation of the Research}

The methods of the research are: theoretical ones - categorical analysis, the methods of systematization, modeling, generalization; empirical methods - the analysis of documents, the analysis of products of the activity, the content analysis of the novel.

\section{The Results of the Research and Their Discussion}

Dominant psychological mechanism for translating activities is the mechanism of orientation, selection and presentation of the translation solution. For example, K. Livingstone (1988) was one of the first scientists who addressed the central question of translation: «How does the interpreter take away the meaning of the message?» Particular attention in the writings of the scholar was given to the subjective semantic conclusion, which in the translated text created a subjective redundancy. In this case the meaning of the message is due to the interaction of the semantic structure of the message, its background knowledge, as well as knowledge relates to the context of the original text.

This psychological mechanism - we mean the mechanism of orientation, selection and presentation of the translation solution we'll show using the examples of the translation of the novel «The Catcher in the Rye» (the author of it is Salinger (1984)) by O. Lohvynenko. In such a way, we'll give examples with the lexical unit «moron». The word «moron» is translater as «iдiom», «болван». The spoken «moron» is translated by O. Lohvynenko in the meaning of «придурок» (Tolkovyj slovar, n.d.):

- «I'm a moron» (Salinger, 2003) - «Я на розум небагатий» (Salinger, 1984).

- «What they did, though, the three of them, when I did it, they started giggling like morons» (Salinger, 2003) - «Але ж вони, помітивщи це, заходилися хихотіти, мов пришелепуваті» (Salinger, 1984). 
Psycholinguistic Mechanisms for Actualization of Translating...

- «I'm not kidding, they were three real morons» (Salinger, 2003) - «Якісь малахольні, слово честі!» (Salinger, 1984).

- In a conversational style is translated the sentence «He was mad about history» (Salinger, 2003) - «Він був просто схиблений на свої історії» (Salinger, 1984). The word «mad» is translated as «хворий», «той, хто страждає від сказу». In spoken language «mad» is used in the sense «виходити із себе», "розлютитися» (Tolkovyj slovar, n.d.).

In the text there are also other sentences with the word «mad»:

- «He was mad about himself» (Salinger, 2003) - «Любив себе до нестями, каналія» (Salinger, 1984).

- «I was so mad, I was practically bawling» (Salinger, 2003) - «I такий я лютий, щзо аж на крик зриваюся» (Salinger, 1984).

- «A couple of minutes later, he was snoring like mad» (Salinger, 2003) - «Через кілька хвилин Еклі вже хропів, як скажений» (Salinger, 1984).

Similarly, in a conversational style is translated «please» not as «будь ласка», but as «зроби ласку»: «Bring it here, please» (Salinger, 2003) - «Зроби ласку, подай-но ї̈ мені» (Salinger, 1984).

The word «shove» (Salinger, 2003) O. Lohvynenko is translated as colloqual «зanuxaє» (Salinger, 1984). In such a way the word combination «dumps them in the river» (Salinger, 2003) is translated in a conversational style «бовть y річку!» (Salinger, 1984). It should be noted that the token «dump» means «глухий звук від падіння важкого предмету» (Tolkovyj slovar, n.d.).

The sentence «Edgar Marsalla, laid this terrific fart» (Salinger, $2003)$ is translated in a conversational style as «Едгар Марсалла <..> як бабахне на всю каплицюю!» (Salinger, 1984). The word «fart» has a meaning «створювати неприємний звук», in spoken language it is translated as «nердіти», «тріскучий звук під час виходу газів із організму» (Tolkovyj slovar, n.d.).

The same situation we have with other examples. So, «<..> old Ackley barged in on me» (Salinger, 2003) is translated as «<..> каналія Еклі рипався до мене разів по сто на день» (Salinger, 1984). The word «barge» means «nерепалка», «лайка». In spoken language this word means «рухатися», «йти», «приходити», «уходити» (Tolkovyj slovar, n.d.). Also O. Lohvynenko uses a spoken variant of the word 
«barge», having translated it as «рипався». Other examples of sentences with a word «barge» are:

- «<..> and old Stradlater barged in, in a big hurry» (Salinger, 2003) - «<..> $i$ в кімнату з розгону влетів каналія Стредлейтер» (Salinger, 1984);

- «Suspense is good for some bastards like Stradlater» (Salinger, 2003) - «3 таким паскудою, як Стредлейтер, часом не завадить $i$ подрочитися» (Salinger, 1984).

The sentence «He hated Stradlater's guts» (Salinger, 2003) is translated as «Бо він терпіти не міг Стредлейтера» (Salinger, 1984). The word «gut» means «вузький прохід» or «протока», «вигин річки», «нутро», «випотрошити». In spoken language the word «gut» means «бадьорість духа», "інтуійія», "внутрішне почуття», "внутрішній голос» (Tolkovyj slovar, n.d.). In the translation of the text «The Catcher in the Rye» O. Lohvynenko used a spoken version of this token in its negative expressive meaning.

The next psychological mechanism of translation the texts is the mechanism of additional expressiveness. With using of this mechanism P. Sokolovskyi translates invective vocabulary (we propose the examples of translation the text «Slaughterhouse-Five or The Children's Crusade: A Duty-Dance with Death» by K. Vonnegut). For example:

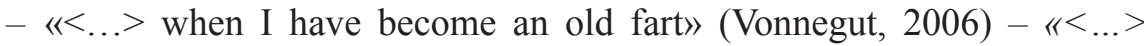
дарма що сам уже зробився старим шкарбуном» (Vonnegut, 2007). Common meaning of token word «fart» is «старик», «дарма втрачати час» (Tolkovyj slovar, n.d.). As invective one «fart» is translated «шкарбун», which makes a kind of additional expressiveness both in the original text and into its translation.

- «<... and I'm an old fart» (Vonnegut, 2006) - «<..> а я зробився старим шкарбуном» (Vonnegut, 2007). In this case the word «fart» is translated as «старче», «даремно гаяти час» (Tolkovyj slovar, n.d.). With additional expressiveness of abusive meaning P. Sokolovskyi translates «an old fart» as «старий шкарбун».

$-\langle<\ldots\rangle$ banged it in the sink» (Vonnegut, 2006) $-\ll<\ldots>i$ без ніякої потреби торохнула лід в умивальник» (Vonnegut, 2007). The word «bang» in colloquial meaning is translated as «xлоп!», «бyx!», «бa-бax!» (Tolkovyj slovar, n.d.). According to this example «торохнула» is also abusive word.

- «Get out of the road, you dumb motherfucker» (Vonnegut, 2006) «Тікай з дороги, ти, так тебе і розтак!» (Vonnegut, 2007). 
Psycholinguistic Mechanisms for Actualization of Translating...

- «Shit» (Vonnegut, 2006) - «Лайно ти» (Vonnegut, 2007). The word «Shit» means «того гляди в штани накладе», "розіграти когось» (Tolkovyj slovar, n.d.). In the text «Slaughterhouse-Five or The Children's Crusade: A Duty-Dance with Death» «Shit» is abusive word and translated as it is (according to general rules of using invective vocabulary).

- «They were festooned with machine-gun belts, smoked cigars, and guzzled booze» (Vonnegut, 2006) - «Вони були обвішані автоматними патронташами, палили сигари ци жлуктили спиртне» (Vonnegut, 2007). The word «guzzle» means «пропивати», «nроїдати». In a spoken language «guzzle» has a meaning «обжертися» (Tolkovyj slovar, n.d.). In this sentence its translation is abusive and also this one added additional expressiveness into the translation of original text.

- «With him was his unpainted whore» (Vonnegut, 2006) - «3 ним була нафарбована хвойда» (Vonnegut, 2007). «Whore» means «жінка легкої поведінки» (Tolkovyj slovar, n.d.). In the meaning of «хвойда» the word «whore» is also abusive one.

Expressiveness is also achieved by P. Sokolovskyi in the translation of vulgarism:

- «<..> kept bobbing up-and down, up-and-down, driving everybody crazy» (Vonnegut, 2006) - «<..> а весь час дибуляв угору-вниз, угору-вниз, що сказитись можна» (Vonnegut, 2007).

- «<...> while he went back for the college bastard» (Vonnegut, 2006) - «<..> доки він сходить по того недоука» (Vonnegut, 2007). «Bastard» means «гібрид», «ублюдок», «байстрюк» (Tolkovyj slovar, n.d.). In this example the translator uses vulgarism «недоук».

Also using the strategy of «finding a functional analogue» P. Sokolovskyi translates slang, which also provides into the text some extra expressiveness:

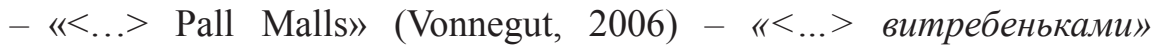
(Vonnegut, 2007). A common meaning of «Pall Malls» is «старовинна гра у шари» (Tolkovyj slovar, n.d.). In this context the word «Pall Malls» is slang. Another example of such a case

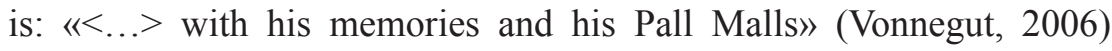
- «<..> зі своїми спогадами ц улюбленими витребеньками» (Vonnegut, 2007).

- «And now you won't pee, you old fool» (Vonnegut, 2006) - «A mu не можеш $і$ nini справлять!» (Vonnegut, 2007). The word «pee» 
is used, as a rule, to indicate the letter «P» (Tolkovyj slovar, n.d.). In this example the meaning «urination» of slang is used.

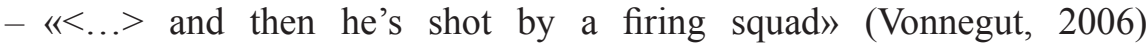
- «<...> a mодi розстріл» (Vonnegut, 2007). The word «squad» means «загін», «команда» (Tolkovyj slovar, n.d.). In this case in the translation we have a slang, which also added additional expressiveness into the translation of the original text.

The next psychological mechanism of translation the texts is the mechanism of freedom in interpretation. This mechanism in a great degree facilitate to find explicit and implicit meanings of the original text by the interpreter. To show this mechanism we also used the translation of P. Sokolovskyi translation the text «Slaughterhouse-Five or The Children's Crusade: A Duty-Dance with Death» written by K. Vonnegut):

- «All this happened, more or less» (Vonnegut, 2006) - «Maйже все ие сталося насправді» (Vonnegut, 2007). In this example the translator tried to reproduce the content that was largely based on the degree of comparison of adjectives.

- «The war parts, anyway, are pretty much true» (Vonnegut, 2006) - «Принаймні війну тут описано досить-таки правдиво» (Vonnegut, 2007).

The next example is: «<..> if the accident will» (Vonnegut, 2006) - «<..> якщо доля судитиме» (Vonnegut, 2007). In this case the word «accident» means «катастрофа», «аварія», «випадок», «нещастя», «прикра обставина» (Tolkovyj slovar, n.d.). In the translation of this phrase we have a deal with the author's equivalent of the translation and psychological mechanism of the translation - the mechanism of freedom in interpretation - takes a place in this case.

One more example is: «Who soliloquized thus to his tool» (Vonnegut, 2006) - «I врешті став до нього промовлять» (Vonnegut, 2007). This example is characterized with the author's equivalent of the translation, because in a case of general meaning the word «soliloquized» means «промовляти монолог», «говорити сам із собою», but the word «tool» in colloquial meaning means «примурок» (a general meaning of «tool» is «інструмент», «знаряддя», «метод», «засіб» (Tolkovyj slovar, n.d.)), which gives the expression the additional expressive value. 
Psycholinguistic Mechanisms for Actualization of Translating...

The next examples with the explication of this psychological mechanism of translation the texts are:

- «And you ruined my health» (Vonnegut, 2006) - «Від слабості в дугу зігнувся» (Vonnegut, 2007).

- «Yes,» I said. «I guess» (Vonnegut, 2006) - «Так, - відповів я. - Либонь, щзо так» (Vonnegut, 2007).

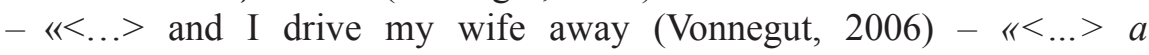
дружина забирається в іншу кімнату» (Vonnegut, 2007).

Among the factors of the efficiency of translation activity, the refusal to contrast linguistic and extra-linguistic, linguistic and encyclopedic knowledge in the case of analyzing the content of the statement would be called. There is no doubt that various aspects of so called «background knowledge», which are considered to be the integral part of translation competence, lead to a depth of perception by the translator (De Simone \& Collina, 2016), which also can not affect the success of translating. However, the latter is also largely determined by the subjective relevance of this activity for a specialist. Subjective actuality, in such a case, which is regulated by a system of personally significant motives, needs and level of aspirations of the translator, will activate the conceptual system of meanings of a specialist of translation activity. As a result, the whole conceptual and communicative experience of the interpreter is reflected, experienced and globally transformed into a conceptual system at different levels of consciousness: sensory and logical, rational, emotional and imaginative, also a linguistic consciousness. The transformed content of the statement arising as a result of these processes is constituted not only by discrete, relatively stable in time and space (as well as by variables, depending on the external context of translation activity) values, but also by dynamic, potentially endless meanings, which are a set of all psychological facts that arise in our minds due to the perception of foreign-language text frames (Ness \& Meltzer-Asscher, 2017). In the translation activity, the transformed meaning should be considered as a continual, mental content, which has significant areas of stability. In such a case values are the most stable, largely unified zones of the development of meaning (Nida \& Taber, 1969).

According to the interpretation of the ratio of meaning and sense adopted in the theories of the activity of translator (Harvey, 
Hunt \& Schroder, 1981; Onufrieva, 2014), we tried to substantiate the meaning of the concept of «translation consciousness». First, the definition of «translation consciousness» directly correlates with the definition of «concept». So, the basic concept of these researchers was the concept. The latter is a collection of all knowledge and ideas of the person associated with a certain reality, determined by the identity of the translator's consciousness, the content of the concept, as well as the translation consciousness, which is the result of the processing of information by the interpreter corresponding to specific frames of consciousness that it is finally consistent with a specific system of concepts and with a unique sense structure within a separate concept (Harvey, Hunt \& Schroder, 1981).

To our mind, the translation consciousness should be considered not only as a construct, a system of signs, but also as a phenomenon that explodes the system of knowledge about the world, as well as the particularities of using the strategies for the implementation of translation activities. Consequently, the translation consciousness is being facilitated, first of all, by the existence of a translator in various images of the world, which allows the interpreter to perform cognitive processing at a high level. Consequently, in the conceptual system of the translator, they must be syncretically represented, although within the various theoretical paradigms differently structured by so called «native» and «in-cultural» concepts.

So, we think, that translation consciousness is a complex dynamic system with a well-structured organization, in which, repeatedly interacting by different parameters, various information about lexical units and equivalent units had being received by the translator as a result of rational, sensory, cultural and social experience which, in its turn, had being processed and stored. The values of lexical units mastered in the context of studying another culture, in the process of socialization, when, by assigning different thematic groups of lexical units, the latter was integrated into stable structures, which were concepts. Naturally, in this case, lexical units automatically induce their appearance with all related information, specify the diverse structures of knowledge, as verbalized and non-verbalized, «experienced» by a translator who were a part of the structure of personally significant experience, accumulated in the conceptual system of the interpreter. Thus, in our research we emphasize the special role of the translation consciousness, its media function in 
Psycholinguistic Mechanisms for Actualization of Translating...

the translation activity, which ensures the ability of a translator to form a multidimensional system of relationships in their own consciousness. The latter facilitates the success of translation activities.

\section{Conclusions}

So, in order to enter the structure of the translation consciousness, each lexical unit has to go through a difficult way, to overcome at least two barriers that arise because of the following reasons: mastering a foreign language under artificial conditions occurs in a rather limited, both quantitative and qualitatively, a stream of information that complicates the development of an image of the world of the interpreter.

Functionality as the ontological characteristic of any system predetermines the ability of its elements to detect and/or to form new qualities in the process of functioning, aimed at achieving the result sought by a translator. Regardless of the level of proficiency in one or more languages, the translator's professional activities are organized according to the principles of a functional system. A positive result in the system of professional activity of the interpreter can be ensured, first of all, because units of this activity (or frames, or scripts) are in the relations related to the compensatory dependence and, in cases of cognitive-discursive difficulties, are able to fill the gap with missing the information at the expense of modification old and/or attraction of new cognitive structures, with the help of which, first of all, changes in the methods of organization of translation activities take place.

To the sphere of so called "compensatory relations», as a rule, the values of both the cognitive structures of the translator and the values included into the content as its actual significant components, due to the translation activity, are usually involved. Constructive syncretism of the translator is largely determined by the nature of the representation of the word in his/her translation consciousness, and this character may vary depending on the professional level of the translator. According to the experimental researchers done by W. Lörscher (1993), there are three such levels, and the information within which the word is a part of the paradigm of a mental space of an interpreter varies in each of them. Thus, scientists believe that in a mental space of a translator the word is associated with scripts that contain information of four types: semantic 
and syntactic, which form the dominant part of a mental space of the interpreter, as well as morphological and phonological information, being included into scripts of a translator.

At the initial stage of mastering a foreign language, acquaintance with the sound and/or graphic form of the word takes place, and knowledge of the meaning of the word becomes understandable either through association with the corresponding equivalent of the word, or they become clear in the light of the definition of the word. However, such information is not yet «embedded» into a complex system of semantic connections of lexical units of the interpreter, it is not a part of its translation consciousness and it is not automatically used in the process of translation activities. This is the first degree of the representation of lexical units, frames and scripts in the translator's minds of a specialist. This level in a great degree is typical for the student, because the presented type of information's organization in the translation consciousness still does not allow to make effective decisions expected from the translator in the process of his/her professional activity. After all, in the process of acquiring foreign language skills, as well as the experience of translating, the ties between the word and the corresponding correlations are greatly strengthened. Due to the regular repetition of the professional activity, such a connection is fixed and reflects the second, mediating stage of the representation of the word in a paradigm of foreign language in the translator's mind. The connection of a word in a foreign language with the concept of a lexical unit in its native language at this level is rather weak, since, in the other way, the progression of the word from the concept to concept is not directly or through the translated equivalent into a foreign language. Also, the information in the translator's minds of a specialist is mediated by a native language. Only in the third, integrative degree, the representation of the word in a foreign language is carried out in the translator's mind of the specialist, that is, the concept is «fixed» in the translator's mind of the interpreter, and the translation activity becomes automatic.

Consequently, the translation consciousness is the ability of the interpreter to carry out his/her professional activities, to reflect, adequately reflect the translation situation, as well as to establish his/her attitude towards the performance of the activity. The necessary component of the translation consciousness is knowledge, as well as the experience of the interpreter that it is the most significant in translating. 
Psycholinguistic Mechanisms for Actualization of Translating...

In such a way the translation consciousness ensures the performance of translation activities at three levels: at associative one, at topical level and also at integrative one.

Constructive transformation, rebuilding and reformatting of frames and scripts by the translator is precisely the result of the interpreter's understanding of the need for translational activity to «rise» from the associative stage to more higher, integrative, in which the translated word is represented by all types of information. The choice in favor of a particular translation solution is always an attempt to realize the essence of his/her own translation consciousness, to reduce the «semantic distance» between native and foreign languages by creating integrated structures that provide updating and transfer of content taking into account the mentality, culture and image of the world of native speakers. Consequently, the constructive transformation, rebuilding and reformatting of frames and scripts by the interpreter, indicating the formation of a specialist's translation consciousness. This process, on the one hand, is determined by the professional activity of the person, and, on the other hand, it is optimized the translation activity.

\section{References}

De Simone, F., \& Collina, S. (2016). The Picture - Word Interference Paradigm: Grammatical Class Effects in Lexical Production. Journal of Psycholinguistic Research, 45 (5), 1003-1019. https://doi.org/10.1007/s10936-015-9388-9

Gutt, E.-A. (1998). Pragmatic Aspects of Translation: Some Relevance-Theory Observations. (The Pragmatics of Translation). In Leo Hickey (Ed.), Topics in Translation (Part 12, pp. 41-53). Clevedon, Philadelphia, Toronto, Sydney, Johannesburg: Multilingual Matters Ltd.

Harvey, O.J., Hunt, D.E., \& Schroder, H.M. (1981). Conceptual System and Personality Organization. New-York: A. Kraft.

Karaban, V.I. (2004). Translation from Ukrainian into English: Translation Course. Kyiv: Taras Shevchenko National University.

Kolomiets, L.V. (2011). Perekladoznavchi seminary: Aktualni teoretychni kontseptsii ta modeli analizu poetychnoho perekladu [Translation Seminars: Contemporary Theoretical Concepts and Models for Analyzing Poetic Translation]. Kyiv: Vydavnycho-polihrafichnyi tsentr «Kyivskyi universytet» [in Ukrainian].

Kovganyuk, S.P. (1968). Praktyka perekladu: z dosvidu perekladacha [Practice of Translation: From the Experience of the Interpreter]. Kyiv: Dnipro [in Ukrainian].

Livingstone, K. (1988). Rolevye igry v obuchenii inostrannym yazykam [Role Play in Language Learning]. Moscow: High school [in Russian].

Lörscher, W. (1993). Translation process analysis. In Y. Gambier \& J. Tommola (Eds.), Proceedings from IV SSOTT '93 "Translation and Knowledge» (pp. 195-221). Turku: University of Turku; Centre for Translation and Interpreting. 
Ness, T., \& Meltzer-Asscher, A. (2017). Working Memory in the Processing of Long-Distance Dependencies: Interference and Filler Maintenance. Journal of Psycholinguistic Research, 46 (6), 1353-1365. https://doi.org/10.1007/s10936017-9499-6

Nida, E.A., \& Taber, C. (1989). The Theory and Practice of Translation. Leiden: E.J. Brill.

Onufrieva, L.A. (2014). Professional self-appraisal at the professional formation of future socionomic specialists' personality. Problems of Contemporary Psychology, 26, 456-467.

Salinger, J.D. (1984). Nad prirvoiu u zhyti [The Catcher in the Rye]. (O. Lohvynenko, Trans.). Kyiv: Molod [in Ukrainian].

Salinger, J.D. (2003). The Catcher in the Rye. OCR \& Spellcheck: Aerius.

Tolkovyj slovar [Explanatory dictionary]. (n.d.). URL: http://www.multitran.ru.

Vonnegut, K. (2006). Slaughterhouse-Five or The Children's Crusade: A Duty-Dance with Death. New-York: Novels.

Vonnegut, K. (2007). Boinia nomer piat, abo Khrestovyi pokhid ditei [SlaughterhouseFive or The Children's Crusade: A Duty-Dance with Death]. (P. Sokolovskyi, Trans.). Kyiv: «Khudozhnia literatura» [in Ukrainian].

Zorivchak, R.P. (1983). Frazeolohichna odynytsia yak perekladoznavcha katehoriia: na materiali perekladiv tvoriv ukrainskoi literatury anhliiskoiu movoiu [Phraseological unit as a category of translation: On Materials of Translations of Novels of Ukrainian Literature into English]. Lviv: Vyshcha shkola: Vydavnychyi dim Lvivskoho Universytetu [in Ukrainian].

\section{АНОТАЦІЯ}

Метою статmі було запропонувати та обгрунтувати визначення «перекладацької свідомості» спеціаліста.

Методи дослідження. Методами дослідження є: теоретичні - категоріальний аналіз, методи систематизації, моделювання, узагальнення; емпіричні методи - аналіз документів, аналіз продуктів діяльності, контент-аналіз тексту роману.

Результати дослідження. Зазначено, що перекладацька свідомість має розглядатися не тільки як конструкт, система знаків, але $і$ як феномен, що експлікує систему знань про світ, а також особливості використання фахівцем стратегій здійснення перекладацької діяльності. Отже, перекладацька свідомість фасилітується, передусім, існуванням у свідомості фахівця різних образів світу, які дозволяють спеціалісту на високому рівні здійснювати когнітивну обробку даних. Наголошено, що в концептуальній системі перекладача мають бути синкретично представлені, хоча у межах різних теоретичних парадигм, по-різному структуровані «рідні» та «інокультурні» концепти. У нашому дослідженні наголошується на особливій ролі перекладацької свідомості, ії медіативній фрункції в перекладацькій діяльності, що забезпечує здатність фахівця утворювати багатовимірну систему зв'язків у власній свідомості; останнє фасилітує досягнення успіху в перекладацькій діяльності. 
Висновки. Зазначено, що перекладацька свідомість є здатністю фрахівця до здійснення професійної діяльності, до рефлексії, адекватного відображення перекладацької ситуації, а також створення свого ставлення щодо виконаної діяльності. Наголошено, що необхідною складовою перекладацької свідомості $\epsilon$ не лише знання, а також й переживання фрахівцем того, що для нього $\epsilon$ найбільшою мірою значущим у перекладацькій діяльності. Підкреслено, що перекладацька свідомість забезпечує виконання перекладацької діяльності на трьох рівнях: асоціативному, актуальному та інтегративному.

Ключові слова: механізм орієнтації, відбору та презентації перекладацького рішення; механізм додаткової експресивності; механізм свободи у тлумаченні тексту.

\section{Ивашкевич Эрнест \& Яцюрик Алла. Психолингвистические механизмы актуализации переводческой деятельности переводчика}

\section{АННОТАЦИЯ}

Целью статьи было предложить и обосновать определение «переводческого сознания» специалиста.

Методы исследования. Методами исследования являются: теоретические категориальный анализ, методы систематизации, моделирование, обобщение; эмпирические методы - анализ документов, анализ продуктов деятельности, контент-анализ текста романа.

Результаты исследования. Отмечено, что переводческая сознание должно рассматриваться не только как конструкт, система знаков, но и как феномен, который эксплицирует систему знаний о мире, а также особенности использования специалистом стратегий осуществления переводческой деятельности. Обосновано, что переводческое сознание фрасилитируется, прежде всего, существованием в сознании специалиста различных образов мира, которые позволяют специалисту на высоком уровне осуществлять когнитивную обработку данных. Отмечено, что в концептуальной системе переводчика должны быть синкретично представлены, хотя бы в рамках различных теоретических парадигм, по-разному структурированные "родные» и «инокультурные» концепты. В исследовании обосновывается особая роль переводческого сознания, её медиативные функции в переводческой деятельности, обеспечивающие способность специалиста образовывать многомерную систему связей в собственном сознании; последнее фасилитирует достижение успеха в переводческой деятельности.

Выводы. Отмечено, что переводческое сознание является способностью специалиста к осуществлению профессиональной деятельности, к рефлексии, адекватному отражению переводческой ситуации, а также создание своего отношения к профессиональной деятельности. Отмечено, что необходимой составляющей переводческого сознания является не только знание, а также и переживание специалистом того, что для него является в наибольшей 
Психолінгвістичні механізми актуалізації перекладацької..

степени значимым в переводческой деятельности. Подчёркнуто, что переводческое сознание обеспечивает выполнение переводческой деятельности на трёх уровнях: ассоциативном, актуальном и интегративном.

Ключевые слова: механизм ориентации, отбора и презентации переводческого решения; механизм дополнительной экспрессивности; механизм свободы в толковании текста. 